\title{
Accommodation and Neutrality Under the Establishment Clause: The Foster Care Challenge
}

\author{
Gregory A. Horowitz
}

Since Everson v. Board of Education ${ }^{1}$ ushered in the application of the establishment clause of the First Amendment ${ }^{2}$ to states, the Supreme Court has sought to define the "blurred, indistinct, and variable barrier"s that separates the religious from the secular. In Everson, Justice Black described the establishment clause in absolute terms," and embraced Thomas Jefferson's "wall of separation" metaphor" as an appropriate image to describe the proper relationship between religion and the state. But the Court soon retreated from the notion that strict separation is possible, or even desirable, ${ }^{6}$ and some have questioned the usefulness of Jefferson's metaphor. ${ }^{7}$ Recognizing that government cannot always avoid involvement in religious affairs, the Court now emphasizes the need for government to maintain "neutrality" towards, rather than separation from, religion. ${ }^{8}$ In

\footnotetext{
1. 330 U.S. 1 (1947).

2. "Congress shall make no law respecting an establishment of religion." U.S. Const. amend. I, c. 1 .

3. Lemon v. Kurtzman, 403 U.S. 602,614 (1971).

4.

The "establishment of religion" clause of the First Amendment means at least this: Neither a state nor the Federal Government can set up a church. Neither can pass laws which aid one religion, aid all religions, or prefer one religion over another. Neither can force nor influence a person to go to or to rrmain away from church against his will or force him to profess a belief or disbelief in any religion. No person can be punished for entertaining or professing religious beliefs or disbeliefs, for church attendance or non-attendance. No tax in any amount, large or small, can be levied to support any religious activities or institutions, whatever they may be called, or whatever form they may adopt to teach or practice religion. Neither a state nor the Federal Government can, openly or secretly, participate in the affairs of any religious organizations or groups and vice versa. In the words of Jefferson, the clause against establishment of religion by law was intended to erect "a wall of separation between church and State."
}

Everson, 330 U.S. at 15-16. Despite this absolutist interpretation, the Court in Everson upheld a New Jersey statute which paid transportation costs of Catholic parochial school students. Although four Justices dissented from the holding, the Court unanimously favored the broad reading of the establishment clause exemplified by the above quote. See id. at 18 (Jackson, J., dissenting) (joined by Frankfurter, J.); id. at 30 (Rutledge, J., dissenting) (joined by Jackson and Burton, JJ.).

5. Letter to the Danbury Baptist Association, 8 JEFF. Works 113, quoted with approval in Reynolds v. United States, 98 U.S. 145, 164 (1878) and Everson, 330 U.S. at 1ó.

6. Zorach v. Clauson, 343 U.S. 306, 312 (1952). See also Grand Rapids School Dist. v. Ball, 473

U.S. 373, 382 (1985); Lynch v. Donnelly, 465 U.S. 668, 673 (1983); Lemon, 403 U.S. at 614.

7. "A rule of law should not be drawn from a figure of speech." McCollum, 333 U.S. at 247 (Reed, J., dissenting).

8. See, e.g., Grand Rapids, 473 U.S. at 382; Wallace v. Jaffree, 472 U.S. 38, 60 (1983); Commit- 
many cases neutrality is achieved through separation, but where separation is impossible it is not yet clear how neutrality is defined.

The establishment clause requires that the secular and religious spheres be distinguished in order to determine whether a governmental action is prohibited. This distinction has been developed by the Court primarily in the context of education, in scrutinizing religious influences in public schools ${ }^{9}$ and government funding of private schools. ${ }^{10}$ The focus on schooling has enabled the Court to develop the idea of religious neutrality under the fiction that religion can always be confined to private life; children can receive and practice religion when they are not in school. This assumption of separability is invalid, however, when government controls every moment of an individual's day and must either provide or decline to offer religious facilities.

The classic examples of such a situation have been military bases and prisons. Government funding of chaplains and other religious services in these cases has been justified, despite apparent establishment clause violations, as a permissible accommodation of the free exercise clause rights of the individuals involved. ${ }^{11}$ But a stronger challenge, which cannot be solved through a "free exercise accommodation" theory," has remained largely unexamined: state foster care policies. Despite evident establishment clause problems with every approach to foster care, there has been only one establishment clause challenge to a foster care scheme: the New York constitutional, statutory, and regulatory scheme for placing foster children according to religion, as applied by New York City, has been challenged in a series of cases in federal court brought by the Children's Rights Project of the American Civil Liberties Union on behalf of a class of black Protestant foster children. ${ }^{13}$ While these cases-Wilder $v$.

tee for Pub. Educ. v. Nyquist, 413 U.S. 756, $792-93$ (1973); Walz v. Tax Comm'n, 397 U.S. 664, 669 (1970); id. at 694 (Harlan, J., concurring); Abington v. Schempp, 374 U.S. 203, 215 (1963); Everson, 330 U.S. 1, 18; id. at 23-24 (Jackson, J., dissenting); cf. Wisconsin v. Yoder, 406 U.S. 205, 220 (1971) (facially neutral regulation violates constitutional requirement of neutrality if it burdens free exercise); Sherbert v. Verner, 374 U.S. 398, 422-23 (1963) (Harlan, J., dissenting) (neutrality requires occasional accommodation of religion).

9. E.g., Engel v. Vitale, 370 U.S. 421 (1962); Abington, 374 U.S. 203.

10. E.g., Everson, 330 U.S. 1.

11. See infra notes $35-44$ and accompanying text.

12. See infra notes $92-114$ and accompanying text.

13. The lack of other establishment clause challenges to foster care is explained by several factors. Funds are rarely available to litigate foster care issues to the appellate stage, and the natural parents are usually incapable of pursuing the matter. Furthermore, not much attention is paid to religion in making foster care placements. For example, in Foster ChILDREN AND tHE CourTs (M. Hardin ed. 1983) [hereinafter Foster ChILDREN], a definitive resource for practitioners in this field, no reference is made to religion as a factor in placement. If religion is especially important to the parents, appropriate placement probably will be arranged informally. The child's advocate would raise religious objections only if doing so promised to improve the quality of the child's placement, or if the child expressed a strong preference. In this latter case, a free exercise claim would be easier to pursue than one based on the establishment clause. Only in New York Gity has the structure of the foster care program made litigation attractive to potential plaintiffs. 
Sugarman ("Wilder I") 14 and Wilder v. Bernstein ("Wilder II,"15 "Wilder III,"16 and "Wilder IV"17) -failed to address the establishment clause problems posed by foster care directly, they provide a useful context for an examination of these problems.

This Note will analyze the establishment clause problems that arise from state involvement in the placement and care of foster children. Section I will compare foster care with other challenges to government's ability to avoid involvement in religious affairs. Section II will demonstrate that establishment clause problems inevitably flow from any state foster care policy. Section III will argue that establishment clause violations in this context cannot be avoided through the "free exercise accommodation" doctrine which has been developed previously, and will suggest that "neutrality" must be reexamined to deal with this challenge. An "establishment clause accommodation doctrine," based on a result-oriented definition of neutrality when separation is impossible, will be adyanced. Because legitimate governmental and religious interests overlap and frequently conflict, steps that seem to keep government and religion apart may have broad effects in both spheres. For the establishment clause to control these effects, content must be given to the concept of neutrality.

\section{Foster Gare as a Ghallenge to Separation}

In the United States, most rights and responsibilities for raising children rest with the parents, in accordance with the strong value placed on the sanctity of the family. ${ }^{18}$ Parents have the right to determine a child's education and religious activities, ${ }^{18}$ subject to the limitations of compelling state interests. ${ }^{20}$ When the natural family is incapable of caring for a child, however, and will not consent to adoption, states must assume parental responsibilities. ${ }^{21}$ This places the state in a unique situation in

14. 385 F. Supp. 1013 (S.D.N.Y. 1974) (three judge court) (per curiam) (upholding facial constitutionality of the New York City foster care scheme).

15. 499 F. Supp. 980 (S.D.N.Y. 1980) (certifying standing for a plaintiff class to challenge scheme as applied).

16645 F. Supp. 1292 (S.D.N.Y. 1986) (approving settlement decree over objections).

17. 848 F.2d 1338 (2d Cir. 1988) (affirming Wilder $I I I$ ).

18. See Santosky v. Kramer, 455 U.S. $745,753-54$ (1982) (state may not terminate parental rights without proof by clear and convincing evidence); Pierce v. Society of Sisters, 268 U.S. 510,535 (1925) (state compelled public school attendance unreasonably interferes with parents' right to direct rearing of offspring); Meyer v. Nebraska, 262 U.S. 390, 399 (1923) (statute prohibiting teaching of foreign languages to grade school children unreasonably interferes with parents' power to control childrens' education).

19. See Pierce, 268 U.S. at 532; Wisconsin v. Yoder, 406 U.S. 205 (1971) (state compelled high school attendanre unreasonably interferes with religious interest of Amish parents).

20. See Prince v. Massachussetts, 321 U.S. 158, 166-68 \& 170 (1944). See also Jacobson v. Massachusetts, 197 U.S. 11 (1905) (state may compel children's vaccinations over parents' religious objections).

21. Natural parents retain certain rights, which usually include visitation rights, the right to a hearing prior to full termination of rights, see infra note 26 , and possibly the right to make significant medical, educational, and religious decisions. See Hardin, Legal Placement Options to Achieve Permanence for Children in Foster Care, in Foster CHILDREN, supra note 13, at 128, 136-37. 
which it controls every aspect of the child's upbringing. As a result, the state cannot evade its responsibility to make decisions that will have a profound effect on a child's religious faith. ${ }^{22}$

\section{A. Background of the Problem}

Foster care has a relatively short and ill-described history as a distinct type of child welfare program. Until the mid-nineteenth century, orphaned or unwanted children were provided for in a variety of ways, including indentures or apprenticeships, placement in almshouses with insane and diseased persons, and other methods that did not involve government intervention, while most reform was accomplished by religious charitable institutions. ${ }^{23}$ Even with the advent of government involvement in the problem, many children were cared for by private institutions such as the New York Children's Aid Society, a Protestant organization that placed children on farms in the West, which were thought to have a better moral climate. ${ }^{24}$ Although the farms were referred to as foster homes, in practice most placements were permanent and the distinction between foster care and adoption had little significance.

Modern protection of the rights of the natural parents has made this distinction extremely important. ${ }^{25} \mathrm{~A}$ family going through difficult times may voluntarily place a child in foster care without abandoning all parental rights; this option is attractive to parents who hope to regain custody when they are better able to care for their child. More frequently, placement is involuntary and authorized by a court through a neglect or dependency proceeding. Foster care placement represents a less drastic and more easily approved form of state intervention than termination of parental rights. ${ }^{26}$

Ideally, foster care is a temporary measure with the goal of returning the child to the natural parents when they are again able to provide care. Unfortunately, of the 251,000 foster children in 1982, over half remained in foster care for more than two years, and nearly one quarter remained for over five years, ${ }^{27}$ often until the child reached majority. ${ }^{28}$ In practice,

22. In this Note, "religion" and "faith" will be used to refer to any set of beliefs falling within the scope of the free exercise and establishment clauses. No attempt will be made to address the serious definitional problems posed by these terms.

23. M. Wolins \& I. Piliavin, Institution or Foster Family: A Century of Debate 10 (1964); Cole, Advocating for Adoption Services, in FOSTER ChILDREN, supra note 13, at 449, 451.

24. M. Wolins \& I. Piliavin, supta note 23 , at 10-13.

25. See Mlyniec, Prosecuting a Termination of Parental Rights Case, in Foster ChILdRen, supra note 13, at 193.

26. To terminate parental rights, a state must prove its case by clear and convincing evidence. Santosky v. Kramer, 455 U.S. 745 (1982). In foster care placements, the burden is generally reduced to a preponderance of the evidence. See, e.g., N.Y. FAM. CT. ACT $\S 1046(\mathrm{~b})$ (McKinney 1983).

27. Staff of Senate Comm. on Finance, 99th Cong., 15t Sess., Staff Data and Materials Related to Foster Care, Adoption Assistance, and Child Welfare Services Under the Social Security Act 4, 25 (Comm. Print 1985) (hereinafter Staff Dara]. The median duration of foster care in 1982 was 25 months, but the mean was 40 months. Id. at $25 ;$ See also id. at 7 
foster care is often continued, even after return to the natural parents is clearly impossible, in order to avoid difficult legal proceedings and to continue receiving government funds. ${ }^{29}$

The general uncertainty and lack of permanency in a foster child's lif $\mathrm{e}^{30}$ is believed to be harmful to the child's social, emotional, and psychological development. ${ }^{31}$ Children are often in foster care during the entire period when they are likely to form their religious beliefs. The content of the religious training (or lack thereof) that such children receive therefore affects their eventual religious faith.

\section{B. Foster Care Compared to Other Challenges to Separation}

Since Everson, the Supreme Court has formulated three criteria to determine whether a governmental action violates the establishment clause. In Lemon v. Kurtzman, ${ }^{32}$ the Court crystallized establishment clause doctrine in the following test: "First, the statute must have a secular legislative purpose; second, its principal or primary effect must be one that neither advances nor inhibits religion; finally, the statute must not foster

("Child welfare researchers noted that the likelihood of a child's leaving foster care decreased with the length of stay.").

28. R. Hubbell, Foster Care and Families 6 (1981). It has been estimated that in 1984 as many as 130,000 children nationwide reached eighteen years of age while in foster care. See Demchak, Services Ordered for Homeless Youths, 6 Yourh L. News 12, 13 (Sept.-Oct. 1985).

29. Hardin, Legal Placement Options to Achieve Permanence for Children in Foster Care, in Foster Children, supra note 13,128, at 139; see infra notes 30-31 and accompanying text.

30. Many foster children are placed in more than one program. "Nearly $60 \%$ of the children in foster care in New York City have experienced more than one placement, and about $28 \%$ have experienced three or more." New York Task Force on Permanency Planning For Children in Foster Care, Report on Permanence Planning iii-iv (March 1986).

31. See generally J. Goldstein, A. Freud \& R. Solnit, Beyond the Best Interests of THE CHILD (1973).

In an attempt to reduce these problems, Congress enacted the Adoption Assistance and Child Welfare Act of 1980, Pub. L. 96-272, 94 Stat. 500 (1980) (codified as amended in scattered sections of 42 U.S.C.) (P.L. 96-272). The Act provides fiscal incentives to the states to prevent unnecessary placements and improve planning by making federal funds contingent upon implementation of alternative services and formulation of a "permanency plan" for each child in foster care. P.L. 96-272 also created a new entitlement program to provide adoption assistance payments to parents adopting children with "special needs," thereby reducing the financial benefit of keeping these children in foster care. For a detailed discussion of this law, see Allen, Golubrock \& Olson, A Guide to the Adoption Assistance and Child Welfare Act of 1980, in Foster ChILdREN, supra note 13, at 575.

P.L. 96-272 has reduced dramatically the number of children in foster care. According to one study, from 1977 to 1982 the number of children in foster care declined from 502,000 to 274,000. See D. Moynihan, Family and Nation 49 (1986). The Senate Finance Committee staff has called the 1977 figure "so far out of line with the data for other years as to appear highly quistionable," STAFF DATA, supra note 27 , at $4 \mathrm{n.3}$, but suggests no alternative figure. There has been less success, however, in reducing the length of foster child placements. From 1980 to 1982, the mean duration of foster care placement declined from 27 months to 25; the median declined from 42 months to 40 . STAFF DATA, supra note 27, at 25 . It seems probable that the federal measures have been more successful in preventing the type of foster care placements that are likely to be short-term (by giving states incentives to provide assistance within the natural family setting) than in solving the problems that lead to long-term foster care.

32. 403 U.S. 602 (1971) (striking down Rhode Island and Pennsylvannia "salary supplements" and other forms of aid to private schools). 
'an excessive government entanglement with religion.' ",33 If a statute fails any one of the three parts of the Lemon test, it is unconstitutional. While the Court has indicated that there are some situations where the establishment clause apparently is violated under the Lemon test and yet the governmental action remains valid, ${ }^{34}$ none of the explanations thus far advanced for abrogating the Lemon test applies to the foster care challenge.

\section{Military and Prisons}

Government funding of chaplains and religious facilities in the military and in prisons has been the subject of extensive litigation and academic discussion. ${ }^{35}$ Although the Supreme Court has not specifically addressed an establishment clause challenge to these programs, ${ }^{36}$ the subject has been used by the Court in dicta as an example of permissible government involvement in religion. ${ }^{37}$

Justice Brennan's lengthy concurring opinion in Abington v. Schemp $p^{38}$ contains the most complete treatment of this issue. Justice Brennan noted that certain practices that seem to violate the establishment clause, including government provision of religious facilities in the armed services and penal institutions, may be necessary to protect the religious liberties guaranteed by the free exercise clause. Brennan distinguished public schools from the armed services and prisons on two grounds. First, there presum-

33. Id. at $612-13$.

34. In addition to the situations discussed in this section, the Court has twice declined to apply the Lemon test. In Marsh v. Chambers, 462 U.S. 783 (1983), the Court rejected a challenge to prayers opening sessions of the Nebraska legislature, emphasizing the long history of such ceremonies, which date back to the First Congress. In dissent, Justice Brennan demonstrated that the practice violated all - three parts of the Lemon test. Id. at 796-801 (Brennan, J., dissenting). In Lynch v. Donnelly, 465 U.S. 668 (1984), upholding a city-funded creche in Pawtucket, Rhode Island, the Court emphasized the secular context of the display and the secular nature of Christmas in general, and criticized "mechanica|l]" application of the Lemon test, although it claimed the holding was not inconsistent with the test. Id. at 678. Again, Justice Brennan argued that Lemon had been violated and expressed hope that the exception created by the majority would be limited. Id. at 695-97 (Brennan, J., dissenting). The Court recently has reaffirmed the Lemon test. See Corporation of Presiding Bishop v. Amos, 107 S. Ct. 2862 (1987); Edwards v. Aguillard, 107 S. Ct. 2573 (1987).

35. See, e.g., Cruz v. Beto, 405 U.S. 319 (1972) (per curiam) (prisons); Katcoff v. Marsh, 755 F.2d 223 (2d Cir. 1985) (military); Kaplan, Military Mirrors on the Wall: Nonestablishment and the Military Chaplaincy, 95 YALE L.J. 1210 (1986); Knight, Religion in Prison: Balancing the Free Exercise, No Establishment, and Equal Protection Clauses, 26 J. CHuRch \& ST. 437 (1984).

36. See Kaplan, supra note 35, at 1210-11. The scarcity of direct challenges to funding is explained by the lack of direct victims. Generally, the harm which the establishment clause forbids is directly symbolic but only indirectly financial (through the use of taxpayers' money to support religion). The ideological groups that support most establishment clause challenges tend to concern themselves with public settings, such as schools or public religious displays, which have greater symbolic impact, ironically overlooking situations where government action has a far more direct impact on individual religious beliefs.

37. Lynch 465 U.S. at 675; Marsh, 463 U.S. at 810-11 (Brennan, J., dissenting); Abington School Dist. v Schempp, 374 U.S. 203, 296-98 (1963) (Brennan, J., concurring); see id. at 309 (Stewart, J., dissenting); Engel v. Vitale, 370 U.S. 421, 449 n.4 (1962) (Stewart, J., dissenting).

38. 374 U.S. at 296-99 (Brennan, J., concurring) (striking state laws requiring public schools to begin each day with Bible readings). While Abington preceded Lemon, it established the standards that were to become the first and second prong of the Lemon test. Id. at 222. 
ably is no coercion to embrace a particular religious faith where adults are involved: "the soldier or convict who declines the opportunities for worship would not ordinarily subject himself to the suspicion or obloquy of his peers." ${ }^{39}$ Second, the absence of religion from public schools does not prevent the child from worshipping at home: "The student's compelled presence in school for five days a week in no way renders the regular religious facilities of the community less accessible to him."40

Neither of these distinctions applies to the foster care setting. Without parental influence to help the child form religious beliefs, the coercive effect of the state's decision as to the religious training of the foster child is far greater than the potential influence of the same decision as to religion in public schools. Furthermore, the state controls (or is responsible for) all possible exposure to religion the foster child may receive. ${ }^{42}$ If, for example, the state refuses to provide religious training to a child, that child will receive no religious training. As Judge Newman wrote in Wilder $I V$, government "extension of financial aid [to private schools] is gratuitous," but in foster care, "the state must take some steps to assure that the religious needs of the children are met."

Moreover, the presence of a free exercise right that would justify state provision of religious training, analogous to the right a soldier or a convict might assert, is problematic, because children, especially younger children, often make no attempt to exercise their free exercise rights. Although it has been suggested that the right could lie elsewhere, particularly with the natural parents, ${ }^{43}$ this Note will argue that free exercise rights cannot be used to determine state policy towards religion in foster care.4t

\section{Adoption}

State approval of an adoption may appear to be a more drastic exercise of state power than maintenance of a child in foster care, and does share many of the same constitutional infirmities. By conferring full parental rights upon adoptive parents, the state makés a decision that is generally more permanent than foster care. Many states have expressly granted to natural parents the right to determine the religion of the adoptive parents. The constitutionality and practical wisdom of this policy was discussed extensively during the 1950's and 1970's. ${ }^{45}$ After these debates, many

39. Id. at 298 .

40. Id. at 299.

41. See infra notes $64-66$ and accompanying text.

42. 848 F.2d at 1348.

43. See infra text accompanying notes 97-100.

44. See infra text accompanying notes 92-114.

45. E.g., Pfeffer, Religion in the Upbringing of Children, 35 B.U.L. REv. 333, 334-35 (1955); Comment, A Reconsideration of the Religious Element in Adoption, 56 CoRNel. L. REv. 780 (1971); Note, Religion as a Factor in Adoption, Guardianship and Custody, 54 Colum. L. Rev. 376 (1954) [hereinafter Columbia Note]; Note, Religious Factors in Adoption, 28 IND. L.J. 401 (1953). 
states repealed statutory provisions requiring that attempts be made to match the religion of the natural parents with the religion of the adoptive parents; nonetheless, approximately one third of the states continue to have some form of religious matching provision for adoptions. ${ }^{16}$ Although there are problems with religious matching in adoption decisions, ${ }^{47}$ adoption poses a lesser challenge to the establishment clause than foster care for two reasons: the state's involvement with an adoption does not continue over an extended period of time, and the state ordinarily does not undertake to fund the adopted child's upbringing. ${ }^{48}$

In most situations where parental rights are terminated, the state awards permanent custody to new parents via adoption. After this occurs, the state's rights and responsibilities are no different than they are for all children. Although the state may use religious factors in determining to whom parental rights will be granted, it cannot enforce any requirements as to the child's religious upbringing after custody is awarded. ${ }^{49}$ Courts occasionally have considered agreements to raise the children in a religion other than that of the adoptive parents in making adoption awards, ${ }^{50}$ but it is doubtful that a court would enforce such an agreement. Once custody is awarded, adoptive parents have the same rights as natural parents, ${ }^{\text {,1 }}$

46. According to a statutory survey in Columbia Note, supra note 45 , at $376 \mathrm{n} .5,43$ states had religious matching statutes in 1954 . Today, 17 states continue to require religious matching in at least some adoption placements. Nine of these states use some form of language approximating the "whenever practicable" standard discussed infra text accompanying note 77. See ARK. STAT. ANN. § 45-435 (1975); MD. Fam. LAw Code ANN. § 5-520 (1984) (state "licensees" shall give "preference" to matching unless natural parents specify otherwise, but courts may or may not consider religion in passing on adoptions, id. at $\S 5-316$ ); Mo. ANN. Stat. $§ 211.221$ (Vernon 1983); Nev. REv. STAT. $\S 62.241$ (1985); N.H. Rev. Stat. ANN. \$ 169:19 (1977); N.Y. ConsT. art. VI, § 32 (1987); Оніо Rev. Code. ANN. $\$ 2151.32$ (Anderson 1976); 20 PA. Cons. Stat. ANN. \$ 5113 (Purdon 1975) ("preferred"); S.C. CODE ANN. \& 20-7-1520 (Law. Co-op. 1985). Four states use more mandatory language. See DEL. CoDE ANN. tit. 13, $\S 911$ (1981) (mandatory unless waived by natural parents); IlL. Rev. Stat. ch. 40, para. 1519 (1981) ("whenever possible"); NEB. Rev. STAT. § 43-509 (1984) ("The religious faith of children . . . shall be preserved and protected"); OKLA. STAт. ANN. tit. 10, § 1119 (West 1987) ("if at all possible"). Three states use matching only when requested by the natural parents. See Ky. REv. STaT. ANN. $\$ 199.471$ (Michie/Bobbs-Merrill 1982) (placements shall not be denied on account of religion unless contrary to the natural parent[s]' expressed wishes); ME. REv. STAT. ANN. tit. 22, $\S 4063$ (Supp. 1987) (matching if requested in writing and appropriate family available); MINn. STAT. ANN. $\S 259.255$ (West Supp. 1988) (matching if explicit parental preference, but apparently subordinate to racial and ethnic matching). California allows institutions to refuse to give up children to adoptive parents of a different faith. CAL. WELF. \& INST. CODE $§ 11264$ (West 1980).

47. See articles cited supra note 45.

48. But see supra note 31.

49. See Pfeffer, supra note 45 , at 358-59.

50. For example, in In re Maxwell, 4 N.Y.2d 429, 151 N.E.2d 848, 176 N.Y.S.2d 281 (1958), a New York court granted custody, over the Catholic natural mother's objections, to a Protestant couple that had agreed to raise the child as a Catholic. The court based the award on the natural mother's sworn affidavit stating that she had no religion, and refused to acknowledge her attempts to repudiate the affidavit; it is unclear whether the adoptive parent's agreement had any effect on the decision.

51. See, e.g., N.Y. DoM. REL. LAw § 117 (McKinney 1983). 
and judicial scrutiny of a child's religious upbringing would violate the religion clauses. ${ }^{82}$

When an adoption is granted, the government generally does not fund the child's upbringing. ${ }^{53}$ With foster care, however, most states are financially responsible for nearly every aspect of the child's daily care, including room, board, and incidental expenses. ${ }^{\text {s4 }}$ Some states explicitly include the cost of religious education, ${ }^{55}$ and those that do not apparently make no attempt to prevent use of government funds for religious purposes. With the exceptions of military, prisons, and legislative chaplains, such direct government funding of religious exercises is rare, if not unique, ${ }^{56}$ and seems to raise serious establishment clause problems.

\section{Possible Approaches to Religion in Foster Care}

When creating a foster care policy, a state can either address the question of religious upbringing or decline to do so. If the state addresses the question, it must decide whether to provide religious training, and, if training is provided, what religion should be taught. The most obvious establishment clause problems arise with regard to this last decision, ${ }^{57}$ but each of the three primary approaches to religion in foster care-secular upbringing, no consideration of religion, and religious matching-violates the establishment clause. The nature of these infringements becomes evident upon an examination of the effects of each policy on the religious beliefs of the individual children involved, as well as on the religious makeup of society as a whole.

52. See Paolella v. Phillips, 27 Misc. 2d 763, 209 N.Y.S.2d 165, 167 (N.Y. Special Term 1960) ("The policy of the law with respect to religious upbringing is one of non-interference."); In re Goldman, 331 Mass. 647, 121 N.E.2d 843, cert. denied, 348 U.S. 942 (1955); Whalen v. Olmstead 61 Conn. 263, 23 A. 964 (1891); Pfeffer, supra note 45, at 350, 356-57. But see infra note 77.

53. But see supra note 31 . Adoptive parents are eligible for welfare programs available to all families, such as Aid to Families With Dependent Children.

54. In New York City, "[a]bout $90 \%$ of the per diem expenses of the children are paid . . . from federal, state, and city funds." Wilder IV, 848 F.2d at 1341.

Pub. L. 96-272, 94 Stat. 500 (1980) (codified as amended in scattered sections of 42 U.S.C.), specifies that foster care payments are intended to cover the cost of food, clothing, shelter, supervision, school supplies, and personal incidentals.

55. States may provide for funding of religious exercises by statute, see, e.g., Ill. ANN. STat. ch. 23, para. 2217, §7(a)(11) (Smith-Hurd 1936) (directing the Department of Social Services to publish regulations requiring child care facilities to "protect[] and foster[] ... the paricular faith of the children served"), or through regulations, see, e.g., N.Y. Comp. CoDEs R. \& REgs. tit. 18, $\$ 441.11$ (1987); MD. REgs. CoDE tit. 11, §§ 07.02.13.10G(4), 07.02.13.12E(3) (1987) (requiring foster care institutions and group homes to provide children with opportunities for worship and other religious activities).

56. But see Religious Schools Get U.S. Aid Abroad, N.Y. Times, Jan. 24, 1988, § 1, at 11, col. 4 (federal Agency for International Development has funded religious schools abroad).

57. For example, it unquestionably would be a violation of the establishment clause for a state to raise all foster children as Protestants. This would violate all three parts of the Lemon test by advancing one religion to the detriment of others. See supra text accompanying notes 32-33. 


\section{A. Secular Upbringing}

Despite the evident establishment clause problems posed by state sponsorship of religious training for foster children, no state has ever applied an analogy to public schools by requiring that foster children be given a secular upbringing. Such a policy would be politically unthinkable; as Justice Douglas said in Zorach v. Clauson, "[w]e are a religious people whose institutions presuppose a Supreme Being."

With older children, it is perhaps feasible for institutions to make religious facilities available at the child's initiative, as is done in the military and in prisons; younger children, however, are not likely to seek religious training on their own. "Voluntarism" has often been meritioned as one of the ideals behind the religion clauses, ${ }^{58}$ but it is unreasonable to demand that young children voluntarily choose their own religious training. ${ }^{80}$ Waiting for a child to choose her religion might be compared to waiting for a child to choose what language she would like to speak; neither language nor religion is likely to come without experience.

If it is true, as seems obvious, that a child raised in a secular environment is less likely to develop religious faith, then a policy favoring secular upbringing would have a determinative effect on the religious beliefs of foster children. Furthermore, the number of people in society with no religious beliefs would probably increase. The Supreme Court often has voiced concern that the establishment clause should not give rise to results that would be hostile to religion. Indeed, when invoking the establishment clause to invalidate a state action, the Court usually insists that it is not "manifest[ing] a governmental hostility to religion or religious teachings." ${ }^{\text {"B1 }}$ Attempts to secularize the foster care environment would tend to inhibit religion and therefore would run afoul of the second prong of the Lemon test, as actions tending to inhibit religion. ${ }^{62}$

\section{B. Religion Not Considered}

In most states, religion is generally not taken into account when making foster care placement decisions. The religious training a foster child will receive, in the absence of her own initiative, will probably be in the faith

58. 343 U.S. 306,313 (1952).

59. See Walz v. Tax Comm'n, 397 U.S. 664, 694 (1970) (Harlan, J., concurring); L. TRIBE, AMERICAN Constitutional LAW $\$ 14-3$, at 1160 (2d ed. 1988) (between principles of voluntarism and separatism, "voluntarism seems to be more fundamental").

60. See Ramsey, The Legal Imputation of Religion to an Infant in Adoption Proceedings, 34 N.Y.U. L. REv. 649, 663 (1959).

61. McCullom v. Board of Educ., 333 U.S. 203, 211 (1948); see also Abington School Dist. v. Schempp, 374 U.S. 203, 225 (1963) (prohibiting Bible readings is not hostile to religion); Engel v. Vitale, 370 U.S. 421, 433-34 (1962) (prohibiting official prayer in public schools not hostile).

62. See supra note 33 and accompanying text. This result becomes extremely important when free exercise interests fail to justify government sponsorship of religious practices. See infra notes 92-114 and accompanying text. 
of the foster family, group home, or institution in which she is placed. Many institutions are openly sectarian in nature, ${ }^{63}$ with no state regulation of proselytizing practices. By allowing the religious question to be settled randomly, states avoid at least the appearance of becoming entangled in religious affairs.

Nonetheless, the foster care experience will inevitably affect the child's religious affiliation. State-designated custodians at all times act under state authority. When a Catholic foster group home brings the children to mass, for example, it does so while exercising the state's in loco parentis power. ${ }^{64}$ This exercise of state power to advance religion cannot be justified by the fact that the state did not intend to influence the children. In the school aid cases, the Court has repeatedly stressed two factors that make state involvement with religious training unacceptable: first, state funds are used to advance religion, even if only to a small degree, ${ }^{65}$ and second, the authority of the state is placed behind the action, thereby implying a state endorsement of the religion. ${ }^{68}$ Both of these factors are present in the foster care setting. ${ }^{67}$

63. R. HubBell, supra note 28 , at $63-65$.

64. The establishment clause only restricts, and can only be violated by, government. The Catholic group home cannot itself be said to violate the establishment clause by promoting religion, but the clause applies broadly to actions by the state that authorize and/or fund such activities. For example, in McCullom, religious groups hired instructors at no expense to the state, and, with the state's permission, held religion classes on public school premises. The Court focused exclusively on the actions of the state and their consequences in holding that use of the public school system and its "compulsory . . machinery" was an unconstitutional state support of religion. 333 U.S. at 211-12; see also Wilder III, 645 F. Supp. at 1314 (unnecessary to consider whether child care agencies are state actors in establishment clause challenge since government policies, not agency policies, are at issue); Libin v. Town of Greenwich, 625 F. Supp. 393, 396 (D. Conn. 1985) (volunteer fire department formed under authority of state law is state actor for establishment clause purposes).

65. See Everson v. Board of Educ., 330 U.S. 1, 33 (1947) (Rutledge, J., dissenting); id. at 40-41 (citing with approval J. Madison, Memorial and Remonstrance Against Religious AssessMENTS I 3 ("That the same authority which can force a citizen to contribute three pence only of his property for the support of any one establishment, may force him to conform to any other establishment in all cases whatsoever."), reprinted in Everson, 330 U.S. at 65-66 (Rutledge, J., dissenting, app.)); see also Engel v. Vitale, 370 U.S. 421, 437, 441 (1962) (Douglas, J., concurring) (public school prayer offends establishment clause by financing religious exercise, even if money involved is small). But cf. Everson, 330 U.S. 1 (public funding of student's expenses in travelling to religious schools not unconstitutional); Walz v. Tax Comm'n, 397 U.S. 664 (1970) (tax exemptions to religious organizations not unconstitutional despite similarity to direct financial support).

66. See McCullom v. Board of Educ., 333 U.S. 203, 226-31 (1948). Justice O'Connor has suggested that endorsement is the crucial evil the establishment clause is intended to prevent. Lynch v. Donnelly, 465 U.S. 668, 690-91 (1983) (O'Connor, J., concurring). State foster care policies may not seem to convey a public message of endorsement, but they could indeed convey such a message to the foster children who receive religious education while under state authority. Cf. G and Rapids School Dist. v. Ball, 473 U.S. 373, 389-91 (1985) ("Shared Time" program where private school students may take secular courses taught by public school employees creates impermissable symbolic connection between religious education and government).

67. A state placement policy oblivious to religion is not likely to affect the religious makeup of the community, as a policy of secular upbringing would. Such effects may, however, be present under certain circumstances. For example, if a religious sect encouraged its members to become foster parents, the state's "religion blind" placement policy would result in a disproportionate benefit to that religion. It is also possible to imagine situations in which this result is intended by the legislature, when the religion in question represents a majority in the state. 


\section{Religious Matching}

As discussed above, many state statutes still require that religion be matched in custody decisions. Many of these statutes apply to both adoption and foster care. ${ }^{68}$ Some states have separate statutes dealing with foster care, including five states that do not practice matching in adoption. ${ }^{68}$ In practice, such statutes may be a poor guide to the actual effect of religion in adoption placement decisions in various jurisdictions. ${ }^{70}$ States with no statutory matching provision may include religion as one of the factors influencing the determination of the "best interests of the child,"71 while the effect of matching statutes is often diluted by loose judicial interpretation. For example, the New York State Constitution mandates that religion should be matched "when practicable," "72 but the New York Court of Appeals has interpreted this to mean that "religion is but one of many factors in the placement of a child for adoption," and religious matching "though desirable, is not mandatory."

A distinction must be made between matching by parental preference and matching by "imputation." placement criterion only when the natural parents express a desire for their child to be raised in a particular faith, while the latter type of matching calls upon the placement agency to determine, in situations where no parental preference has been expressed, the "religion of the

68. ARk. Stat. ANn. $\S 45-435$ (1975); ME. Rev. Stat. AnN. tit. 22, § 4063 (1964); MD. Fam. Law Code Ann. \$ 5-520 (1984); Mo. Ann. Stat. \$211.221 (Vernon 1983); Neb. Rev. Stat. § 43-509 (1984); Nev. Rev. Stat. AnN. \$ 62.241 (Michie 1985); N.H. Rev. Stat. ANN. § 169:19 (1977); Ohio Rev. Code. Ann. § 2151.32 (Anderson 1953); Okla. Stat. AnN. tit. 10, $\$ 1119$ (West 1987); 20 Pa. Cons. Stat. ANN. $\$ 5113$ (Purdon 1975); S.C. Code ANN. $\$ 20-7-1520$ (Law. . Co-op. 1985).

69. Cal. Welf. \& INST. Code $\S 205$ (West 1984) ("so far as practical"); ConN. Gen. Stat. § 17-36 (1985) ("if practical" and "faith is known or [reasonably] ascertainable"); ILL. ANN. STAT. ch. 23, para. 5007 (Smith-Hurd 1981) ("as far as possible"); Mass. Gen. LAwS ANN. ch. 119, § 32 (West 1965) ("unless sufficient reason [precluding matching] is noted in the record"); MINN. STAT. ANN. \$ 518.17(1)(i) (West 1987) (defining religion as factor going to best interests); N.Y. Soc. SERv. LAw $\S 373$ (1) (McKinney 1983) ("as far as practicable"); W. VA. CoDE $\$ 49-2-1$ (1986) (same); Wis. STAT. ANN. $\$ 48.62$ (West 1957) (authorizing agencies to provide training in religion of natural parents); WYo. STAT. \$14-6-221(j) (1977) ("when practicable" and "choice of equivalent services exists"). Among these states, Connecticut, Massachusetts, West Virginia, Wisconsin, and Wyoming have no religious matching in adoption. Only Delaware has an adoption matching statute without a statute applying to foster care. See supra note 46 (adoption statutes).

70. See Columbia Note, supra note 45 , at 376 .

71. "Best interests" may be defined by statute or case law. Minnesota by statute includes religion as a factor in determining "best interests." MinN. STAT. ANN. $\$ 518.17(1)(h)$ (West Supp. 1988).

72. N.Y. Const. art. VI, $\S 32$. New York is unique in mandating religious matching in its constitution. L. Pfeffer, Church State and Freedom 709 (rev. ed. 1967). The elevation of this principle to constitutional status in 1921 was the result of a long history of concern for religious interests in child welfare. See Wilder v. Sugarman, 385 F. Supp. 1013, 1020 (S.D.N.Y. 1974).

73. Dickens v. Ernesto, 30 N.Y.2d 61, 65, 281 N.E.2d 153, 155, 330 N.Y.S.2d 346, 348 (1972), appeal dismissed, 407 U.S. 917 (1972); see also, e.g., In re Walker, 159 Cal. App. 2d 463, 324 P.2d 32 (1958) (similar language in California matching statute not mandatory, but child's welfare paramount).

74. See Note, Religious Matching Statutes and Adoption, 51 N.Y.U. L. REv. 262, 264 \& passim (1976). 
child" and to place the child accordingly. Matching by parental preference is arguably necessary under the "parental rights theory" to protect the natural parents' right to determine the religious upbringing of their children. ${ }^{76}$ This argument is stronger in the case of foster care than adoption since the natural parents retain many parental rights; ${ }^{76}$ requiring religious matching "when practicable" allows courts to balance compelling state interests against free exercise rights and to refuse to consider religion only when doing so would clearly be detrimental to the child. ${ }^{77}$

Matching by parental preference can minimize the impact of state intervention on the religious upbringing of the individual foster child by giving the child (somewhat) the same religious training that her natural parents would have provided. But this is not a comprehensive policy towards religion in foster child placement; it must be supplemented with a policy addressing the numerous cases where no preference is expressed. For example, New York City allows natural parents to complete a form designating religious preference, including a "no preference" option, but in nearly eighty percent of placements the form is not completed. ${ }^{78}$ In these instances, one of the other alternatives discussed-secular upbringing, no religious consideration, or matching by imputation-must be applied.

Matching by imputation is statutorily required by a number of states, ${ }^{79}$ but New York may be the only jurisdiction that continues actively to engage in the practice. The New York statute mandates that placement must be made to an agency or institution "under the control of persons of the same religious faith or persuasion as that of the child."80 The "religion of the child" is defined under the statute as either the expressed preference of the parent, or, "[i]n the absence of expressed religious wishes . . . it shall be presumed that the parent wishes the child to be reared in the

75. See infra notes $97-100$ and accompanying text.

76. See Note, supra note 74 , at $280-81$. One commentator has argued that the parental rights theory cannot justify religious matching requirements in cases of involuntary foster care because "once parental unfitness invokes state intervention, the child's welfare takes precedence over parental prerogatives." Note, Constitutionality of Mandatory Religious Requirements in Child Care, 64 YALE L.J. 772, 785 (1955). This analysis would support using religion only as a factor in determining the child's best interests, but historically courts have required a compelling state interest in the child's welfare, such as imminent physical harm, to justify interference with parental free exercise rights. See supra note 52 and accompanying text.

77. Religious matching would be detrimental to the child if it resulted in the child being placed in an otherwise less desirable setting, or if it required the child to spend time in an institutional setting while waiting for a suitable "in-religion" foster home to become available, or if the religious practices themselves are harmful to the child. E.g., In re State (Interest of Black), 3 Utah 2d. 315, 283 P.2d 887 (1955) (children adjudged neglected because parents were Mormons practicing polygamy), cert. dented, 350 U.S. 923 (1955). But see Sanderson v. Tryon, 739 P.2d 623 (Utah 1987) (distinguishing Black; polygamy not conclusive reason to deny custody in divorce).

78. Brief for Plaintiff-Appellees at 20, Wilder v. Bernstein, 848 F.2d 1338 (2d Cir. 1988) (Nos. 87-7406, 7408, 7410) [hereinafter Plaintiff's Brief].

79. All of the foster care-specific matching statutes, supra note 69 , and many of the general custody statutes, supra note 68 , require imputation if literally applied.

80. N.Y. SOC. SERv. LAw § 373(1) (McKinney 1983). 
religion of the parent." ${ }^{\text {81 }}$ Evidence suggests that the religion of the parents may be determined by inferences from their surname or ethnicity, case worker observations of religious symbols, and other speculative means. ${ }^{82}$

Imputation will invariably alter the religious upbringing of many children, since the assumptions behind it are not universally valid. Evidence of the natural parents' faith can be misleading. More importantly, the assumption that parents would raise children in their own "religion," often similarly imputed, is frequently incorrect: many parents do not practice or teach the religion in which they were raised. Consequently, matching by imputation is likely to result in more children receiving religious training as a result of foster care.

The New York scheme essentially imputes a religious faith to the child and then, acting in loco parentis, asserts either the child's or the parents' free exercise rights on their behalf. ${ }^{83}$ The constitutionality of legal imputation of religion to the child has been vigorously assailed. ${ }^{84}$ Professor Pfeffer has called such an imputation "exactly what an establishment of religion is-the imposition of a religious status by political authority." Furthermore, imputation of religious status requires accepting one of various religious doctrines regarding when a person acquires, or becomes a member of, a religion; ${ }^{86}$ state recognition of one religious doctrine over another is prohibited by the establishment clause. ${ }^{87}$

The settlement negotiated with New York City and approved by the Second Circuit in Wilder $N$ will effectively terminate matching by imputation in New York City. ${ }^{88}$ The plaintiffs in the Wilder cases were motivated at least as much by the prospect of receiving better foster care services in a "first-come, first-served" placement scheme without religious matching as they were by a feeling that the establishment clause was vio-

81. N.Y. SOC. SERv. LAw § 373(7) (McKinney 1983).

82. Interview with Marcia Robinson Lowry, Director of the Children's Rights Project of the American Civil Liberties Union (plaintiffs' counsel in Wilder cases) (November 25, 1987) (summarizing depositions of foster care professionals in New York City).

The New York imputation procedures have been defended by their draftsman, Shad Polier, as representing reasonable inferences about what the expressed parental preference would be if it had been obtained. Polier, Religion and the Child, N.Y. L.J., May 25, 1970, at 1, col. 5.

83. See infra notes $92-114$ and accompanying text (criticizing reliance on free exercise rights).

84. See, e.g., Pfeffer, supra note 45; Ramsey, supra note 60 .

85. Pfeffer, supra note 45 , at $384-85$.

86. Conflicts over this area of religious doctrine have led to disputes of precisely the type that the establishment clause should prevent. See Lemon v. Kurtzman, 403 U.S. 602, 625 (1971). For example, in 1858 Europe was divided by the hostile conflict arising from Pope Pius IX's refusal to release a Jewish infant who had been forcibly removed from his home by papal guards after his Catholic nurse had surreptitiously baptized him. 9 JEwish ENCYClopedia 35-36 (1905) (quoted in Pleffer, supra note 45 , at 334 n.12).

87. See Ramsey, supra note 60 , at $668-75$. Courts have occasionally blundered into pronouncements about the validity of sacramental acts in determining a child's religion. See, e.g., Matter of Santos. 278 A.D. 373, 105 N.Y.S.2d 716 (1951) (finding that two girls who had been baptized were Catholic, despite intensive Jewish training while young), appeal dismissed, 304 N.Y. 483, 109 N.E.2d 71 (1952).

88. Religious matching in the rest of New York state was unaffected by the Wilder litigation. 
lated, ${ }^{89}$ and this concern is reflected in the nature of the settlement. The settlement states two main goals for the New York City foster placement scheme: "[T]o ensure that all . . . children . . . receive services without discrimination on the basis of race or religion and have equal access to quality services and to ensure that appropriate recognition be given to a statutorily permissible wish for in-religion placement. . . ."90 In essence, the new placement scheme will be one of matching by parental preference with no religious consideration in the absence of expressed preference. ${ }^{91}$

\section{Accommodation of ReLigion in Foster Gare}

Neither the body of establishment clause jurisprudence since Everson nor the Wilder litigation has resulted in an adequate justification for government activities that have radical effects on religious life. Such an explanation must be developed if courts are to apply a principled approach when refereeing interactions between church and state.

\section{A. The Wilder I Decision: Free Exercise Accommodation}

When the Wilder litigation began in 1973, the district court, on its own motion, considered whether the New York foster care scheme on its face violated the establishment clause. ${ }^{92}$ In considering the statutory scheme

89. Plaintiffs also alleged that their free exercise rights were violated by policies of the sectarian institutions, particularly the refusal of Catholic institutions to provide birth control and abortion information. Wilder $I I I, 645$ F. Supp. at 1303 . The settlement guarantees access to such information and protection of the children's free exercise rights by requiring agencies to provide all children with the opportunity to practice their religion, and by protecting them from compelled religious practices. Proposed Stipulation of Settlement para. 70, Wilder III, 645 F. Supp. 1292 (78 Civ. 957) [hereinafter Settlement]. For a summary of the settlement, see Wilder III, 645 F. Supp. at 1304-07 \& passim.

90. Settlement, supra note 89 , at para. 4 .

91. The settlement reached between plaintiffs and New York City calls for a classification and ranking of child care programs to be performed by outside consultants. Settlement, supra note 89 , at paras. 6-8. A child would be placed in the best available program, without regard to religion, unless the natural parent(s) expressed a religious preference. $1 d$. at para. 24 . The settlement also requires that case workers fully explain the options for religious placement to natural parents, in an attempt to avoid situations where parental wishes must be inferred. Id. at para. 57. The parent is given the option of (a) having the child wait until a vacancy occurs in the best "in-religion" program, (b) having the child placed in the next best "in-religion" program, or (c) having the child placed in the best available "out-of-religion" program. Id. at para. 30. The settlement also strictly defines the situations in which an agency can reject a placement; religious factors are not considered valid. Id. at para. 34.

92. The court distinguished Dickens v. Ernesto, 30 N.Y.S.2d 61 (1972), which upheld the constitutionality of religious matching when practicable with regard to adoption, on the grounds that in Dickens no state funding was involved in adoption placement. Wilder $I, 385 \mathrm{~F}$. Supp. at 1023. See also supra notes 59-62 and accompanying text.

Since the Wilder $I$ court took up the question of the facial constitutionality of the New York program on its own motion before any factual record was developed, plaintiffs' counsel elected not to appeal the ruling. Instead, they pursued the claim that the New York scheme was unconstitutional as applied, since they believed that the facts strongly supported the plaintiff's case. Interview with Marcia Robinson Lowry, Director of the Children's Rights Project of the American Civil Liberties Union (plaintiffs' counsel in Wilder cases) (November 25, 1987). New York City's Corporation Counsel apparently shared this belief and negotiated a settlement that promises to reshape New York's foster care scheme dramatically. See Plaintiff's Brief, supra note 78, at 19 (quoting affidavit of Frederick A.O. Schwarz, Jr.). 
described above, the court concluded that the scheme violated both the purpose and effect prongs of the Lemon test. The court found that religious matching has a "principal objective . . . to provide for the religious education of foster children in accordance with the parents' wishes," that this purpose is not secular. ${ }^{94}$ Further, the court found that the express provision of funds for religious training "directly support[s] the religion involved." Bs Because violation of any prong of the Lemon test is sufficient to render a statute unconstitutional, the court did not consider whether the New York scheme created excessive entanglement with religion. ${ }^{98}$

Recognizing that apparent establishment clause violations occasionally have been held valid nonetheless, ${ }^{97}$ the court considered whether any free exercise rights were protected by the New York scheme, ${ }^{98}$ and identified two sets of such rights in the foster care setting: those of the natural parents, and those of the foster child.99 The court then held that the scheme "represent $[\mathrm{s}]$. . . a fair and reasonable accommodation between the Establishment and Free Exercise Clauses." "100

One commentator has asserted that the Wilder I court went beyond the Supreme Court rulings recognizing a parent's right to control a child's religious upbringing ${ }^{101}$ by extending the right to parents without custody. ${ }^{102}$ If this is so, such a step is not unjustified; retention of parental rights must be assumed absent a compelling reason for the state to infringe upon them. ${ }^{103}$ Indeed, while the Second Circuit in Wilder IV rejected the claim that parents have a constitutional right to same religion placement, it acknowledged that some free exercise interests exist: "So long as the state makes reasonable efforts to assure that the religious needs of the children are met during the interval in which the state assumes parental responsibilities, the free exercise rights of the parents and their children are adequately observed." 104 More important was the court's un-

93. Wilder I, 385 F. Supp. at 1024.

94. Id. Recently, the Supreme Court indicated that alleviation of government interference with religious interests is a secular goal and therefore a legitimate purpose for state legislation. Amos v. Corporation of Presiding Bishop, 107 S. Ct. 2862, 2868 (1987). However, the New York scheme still appears to violate the effect and entanglement prongs of the Lemon test. See infra note 96 and accompanying text.

95. Wilder I, 385 F. Supp. at 1024.

96. The Wilder III court indicated that the New York scheme does involve entanglement, and questioned the Wilder I court's conclusion that the alternative of state-run, non-sectarian agencies would result in greater entanglement. Wilder III, 645 F. Supp. at 1332.

97. See supra note 34 and accompanying text.

98. Wilder I, 385 F. Supp. at 1025.

99. Id. at 1026 .

100. Id. at 1029 .

101. See supra note 21.

102. Note, supra note 74. This argument may have been influenced by the author's focus on adoption, in which all parental rights are terminated.

103. See supra notes $18-21$ and accompanying text.

104. 848 F.2d at 1347. 
stated inference of an exercise of parental rights in the large majority of cases where the natural parents express no religious preference, and consequent failure to address the problems associated with imputation. ${ }^{105}$

The court in Wilder $I$ attempted to justify this inference by casting a duty on the state to assert the parents' free exercise rights in their absence. ${ }^{108}$ The notion that the state can claim free exercise rights is a fiction that fails to remedy the defects of the parental rights theory. ${ }^{107}$ No government body has free exercise rights, ${ }^{108}$ but for the Wilder I court, "the state must wear two hats, one as a surrogate parent obligated to enforce the biological parent's rights ... and the other as a government. . ." "108 Without citing any precedent, the court cast the state in the role of the natural parents' agent, and reasoned that this role justifies an unprecedented state claim of free exercise. In fact, however, when the state exercises control over the foster child, it does so in its own right. ${ }^{110}$

The court also found that the state has the duty "of fulfilling the child's Free Exercise rights"111 which arises from the state's role as "surrogate parent." But the Supreme Court cases cited on this point actually involve parents asserting their own free exercise right to control the religious upbringing of their children, rather than parents asserting the childrens' rights. ${ }^{112}$ This misinterpretation of precedent is not necessarily fatal; .even if the state is not an agent of the natural parents for purposes of protecting the religious rights of the children, the Wilder I court's identification of foster childrens' free exercise rights could be valid. The argument is most plausible when the child is of sufficient age to express a preference; if the state, or an agency, refuses a child's request to make available religious training, a free exercise suit would probably succeed. ${ }^{113}$

With younger children, however, the argument fails. Imputing religion to a child not old enough to assert a religious faith on her own involves an impermissible imposition of religion on the child by the state. ${ }^{114}$ The free exercise accommodation doctrine relied upon by the Wilder $I$ court justifies New York's foster care scheme only if no attention is paid to the case of younger children whose parents have not asserted their religious rights.

105. See supra notes $79-87$ and accompanying text.

106. 385 F. Supp. at 1026.

107. See Note, supra note 74 , at $282-83$.

108. See Libin v. Town of Greenwich, 625 F. Supp. 393, 396 (D. Conn. 1985); Wilder III, 645

F. Supp. at 1325; M. Yudof, When Government Speaks 42-50 (1983).

109. 385 F. Supp. at 1026.

110. See Note, supra note 74 , at 283.

111. 385 F. Supp. at 1026.

112. See supra note 19.

113. The plaintiffs in Wilder did make such a claim. See supra note 89.

114. See supra notes $79-87$ and accompanying text. 


\section{B. Establishment Clause Accommodation}

The court in Wilder I was misled by the analogy to the military and prisons. ${ }^{115}$ The Supreme Court's use of these examples of permissible sponsorships of religion ${ }^{116}$ has led numerous commentators and the Wil$\operatorname{der} I$ court to conclude that the presence of free exercise rights was crucial in justifying these apparent violations of the establishment clause. ${ }^{117}$ But the Supreme Court itself has never relied exclusively on a threat to free exercise interests to uphold a statute. As Justice Brennan has made clear, the Court speaks of general accommodation of religion rather than of accommodation of free exercise: "[T] he Court's decisions have indicated that the limits of permissible governmental action with respect to religion under the Establishment Clause must reflect an appropriate accommodation of our heritage as a religious people whose freedom to develop and preach religious ideas and practices is protected by the Free Exercise Clause."118 Moreover, the Court has emphasized that "the limits of permissable state accommodation of religion are by no means co-extensive with the noninterference mandated by the Free Exercise Clause."119

Gases in which free exercise is apparently a factor can be explained more compellingly by an accommodation doctrine based exclusively on the establishment clause: when every possible policy offends the establishment clause, the state must pursue the policy that seeks neutrality. Within this doctrine, infringements of free exercise interests are considered as manifestations of government hostility towards religion.

The Wilder I court could not strike down the New York religious matching statutes in the absence of a less violative alternative. ${ }^{120}$ As discussed above, every possible foster care policy entails establishment clause violations. ${ }^{121}$ But the inevitability of establishment clause problems must not force states to abandon foster care programs entirely (as well as all other social programs which involve the state in the affairs of daily life). Nor should this inevitability lead to a complete suspension of judicial scrutiny of establishment clause problems in situations where separation is impossible. Judicial intervention clearly would be justified if a state were

115. 385 F. Supp. at 1026. Other courts and commentators have been similarly misled. See, e.g., Carter v. Broadlawns Medical Center, 667 F. Supp. 1269 (S.D. Iowa 1987) (hospital receiving public funds may employ chaplain to protect free exercise rights of confined patients); Knight, supra note 35 .

116. See supra note 37.

117. See, e.g., Knight, supra note 35 .

118. McDaniel v. Paty, 435 U.S. 618 (1978) (Brennan, J., concurring in judgment); see also Lynch v. Donnelly, 465 U.S. 668, 673 (1983): Committee for Pub. Educ. v. Nyquist, 413 U.S. 756, 760 (1973).

119. Walz v. Tax Comm'n, 397 U.S. 664, 673 (1970).

120. Wilder 1,385 F. Supp. at 1028.

121. See supra notes 57-87 and accompanying text. The Children's Rights Project of the ACLU takes the pusition that, due to the lack of separation caused by the foster care situation, permanent custody should be stressed as a goal in child placement. See American Civil. Liberties Union, Poilk:y Guint. 362-66 (rev. ed. June 1986) (Policy \#272(c)). 
to mandate that all foster children be raised as Protestants. In approving the stipulated settlement, the Wilder III court found that the stipulation "presents no greater danger of impermissibly advancing religion than exists under the present system of foster care upheld on its face in Wilder I."122

\section{Neutrality as a Standard}

Weighing the relative seriousness of establishment clause violations is difficult. The Lemon test identifies three distinct types of violation, but the Court has not attempted to rank these types in importance. The Wilder III court had difficulty in making this judgment; the proposed settlement would be less likely to advance religion impermissibly than the existing scheme, ${ }^{123}$ but it seems to involve greater entanglement. ${ }^{124}$ Can these variables be fit into a single equation? The relative weights will be determinable only if a unitary standard is developed. This standard can be found by defining neutrality.

\section{Neutrality Defined}

"Neutrality" originated as a description of a country's allegiances during wartime. ${ }^{125} \mathrm{~A}$ neutral country endeavors to take no part in the conflict and is, ideally, indifferent to the outcome. This wartime metaphor may seem inappropriate to apply to the religion clauses, but it is accurate in at least one respect: in the American religious domain, government should endeavor not to affect the outcome.

One way in which neutrality usually can be achieved is through complete non-involvement. For example, government wisely avoids monitoring the content of sermons, or adjudicating intramural religious disputes. This passive neutrality is feasible, however, only where government is modest in its powers and responsibilities. When government assumes a greater role, its actions and its inactions will frequently have effects in the religious sphere, including the religious faiths of foster children. Passivity is not always neutral; for example, a debate moderator who does nothing to restrain on debator's abuse of the rules surely is not neutral. Therefore, an active consideration of the impact on religion may be necessary to insure neutrality.

Professor Kurland has argued that neutrality can be achieved only through what might be termed obliviousness: "religion may not be used as a basis for classification for purposes of governmental action, whether that action be the conferring of rights or privileges or the imposition of duties

122. Wilder III, 645 F. Supp. at 1333 (emphasis in original).

123. Id.

124. Id. at 1337

125. See Black's Law Dictionary 939 (5th ed. 1979). 
or obligations."126 But the Court has rejected Kurland's thesis as a "rigid conception of neutrality" which fails to account for situations in which religious classifications are necessary to avoid hostility towards religion. ${ }^{\mathbf{2 7}}$ Obliviousness is sometimes hostile rather than neutral, because neutrality is measured by the expected effect of one's actions. Neutrality can be defined only as a goal, not as a method.

Neutrality towards religion means that government should attempt not to alter the outcome of a religious situation through its involvement. When involvement is unavoidable, neutrality may demand an active accommodation of religious interests to avoid having government action produce repercussions in the religious sphere. All approaches to religion in foster care have some inevitable transformational tendencies for the individual children involved, and, to a lesser degree, for society as a whole. Requiring a secular upbringing would give many children a more secular upbringing than they would otherwise receive, and would result in less religion being practiced on the whole. Religious matching, on the other hand, tends to lead to opposite results. And while ignoring religion as a factor may or may not have effects on the general religious composition of society, by leaving the religious fate of the child to chance this policy maximizes the tendency to transform the individual child's religious experiences.

\section{Wilder and Beyond}

The New York foster care scheme, especially as modified by the settlement in Wilder III, can be justified, though on a far different theory from the one relied upon by the Wilder I court. The state's policy should be judged by its tendency to give children the same religious upbringing as they would have had if the state had not intervened. When the transformational tendency is used to evaluate the relative neutrality of state policies in foster care, the policy of matching by preference with religion not otherwise considered appears to be the best approach possible, since it minimizes the effect of foster care on the religious upbringing of the child when evidence is available, and minimizes the effects on society in those instances where evidence is lacking.

\section{Conclusion}

The establishment clause is easiest to apply in situations where strict separation is possible. In many situations, including foster care, strict separation is not possible, and the establishment clause cannot be interpreted to prevent governmental involvement in these areas. The examination of

126. P. Kurl.and, Rel.IGION and THE LAw 18 \& passim (1962).

127. McDaniel v. Paty, 435 U.S. 618, 638-39 \& nn.17-21 (1978) (Brennan, J., concurring) (citing cases). 
foster care presented above should serve the same purpose as a controlled scientific experiment: by removing the variable of free exercise rights as a solution to a situation in which separation is impossible, we discover that the establishment clause is-must be-sufficient in itself to produce religious accommodation. Government must be neutral towards religion, but neutrality cannot be captured through any singular method. Instead, neutrality must be understood to consist of a sensitivity to the effects of government activity and an attempt to minimize the transformational consequences of these effects.

The arguments offered above have implications for areas more visible than foster care. For example, commentators have argued that the Supreme Court's rulings excluding religion from public schools result in government hostility towards religion rather than neutrality, ${ }^{128}$ and recently critics have claimed that public school curriculum is leading to the secularization of society. ${ }^{129}$ This type of outcome-oriented argument may be valid, if it is presented with a careful consideration of the transformational tendencies of the alternatives.

128. See, e.g., Louisell, Does the Constitution Require a Purely Secular Society?, 26 CATH. U.L. Rev. 20 (1976); McConnell, Neutrality Under the Religion Clauses, 81 Nw. U.L. Rev. 146 (1986).

129. See, e.g., Note, The Myth of Religious Neutrality by Separation in Education, 71 VA. L. REv. 127 (1985), Note, The Establishment Clatuse, Secondary Religious Effects, and Humanistic Education, 91 YaLE L.J. 1196 (1982). 
